\title{
Prevalence of autosomal dominant polycystic kidney disease in Persian and Persian-related cats in Brazil
}

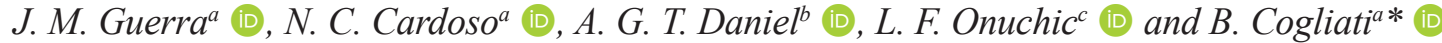 \\ a Laboratório de Patologia Morfológica e Molecular, Departamento de Patologia, Faculdade de Medicina Veterinária e \\ Zootecnia - FMVZ, Universidade de São Paulo - USP, Av. Prof. Dr. Orlando Marques de Paiva, 87, Cidade Universitária, \\ CEP 05508-270, São Paulo, SP, Brasil \\ bGattos - Clínica Especializada em Medicina Felina, Av. Vereador José Diniz, 3165, Campo Belo, CEP 04603-002, \\ São Paulo, SP, Brasil \\ 'Faculdade de Medicina, Universidade de São Paulo - USP, Av. Dr. Arnaldo, 455, Cerqueira César, CEP 01246-903, \\ São Paulo, SP, Brasil \\ *e-mail: bcogliati@usp.br
}

Received: August 10, 2019 - Accepted: January 21, 2020 - Distributed: May 31, 2021

(With 1 figure)

\begin{abstract}
Autosomal dominant polycystic kidney disease (ADPKD) is the most common genetic disease in cats. However, scarce data on its prevalence are available in Brazil. Persian cats and Persian-related breeds were assessed by molecular genotyping for a $\mathrm{C}$ to A transversion in exon 29 of PKD1 gene to determine ADPKD prevalence in a Brazilian population. Genomic DNA extracted from peripheral whole blood or oral swabs samples was used to amplify exon 29 of $P K D 1$ gene employing a PCR-RFLP methodology. From a total of 616 animals, 27/537 Persian and 1/17 Himalayan cats showed the single-nucleotide variant ( $\mathrm{C}$ to $\mathrm{A}$ ) at position 3284 in exon 29 of feline PKD1. This pathogenic variation has been identified only in heterozygous state. The prevalence of ADPKD in Persian cats and Persian-related breeds was $5.03 \%$ and $1.6 \%$, respectively. There was no significant association between feline breed, gender or age with ADPKD prevalence. Of note, the observed ADPKD prevalence in Persian cats and Persian-related breeds in Brazil was lower than the ones reported in other parts of the world. This finding may be related to genetic counseling and consequent selection of ADPKD-free cats for reproduction.
\end{abstract}

Keywords: feline, genetic disorder, polymerase chain reaction, genotyping, Felis catus.

\section{Prevalência da doença renal policística autossômica dominante em gatos Persas e raças relacionadas no Brasil}

\begin{abstract}
Resumo
A doença renal policística autossômica dominante (DRPAD) é a doença genética mais comum em gatos. No entanto, poucos dados sobre sua prevalência estão disponíveis no Brasil. Gatos Persas e de raças relacionadas foram avaliados por genotipagem molecular para a transversão $\mathrm{C} \rightarrow \mathrm{A}$ no exon 29 do gene $P K D 1$ felino para determinar a prevalência de DRPAD. DNA genômico extraído de sangue total periférico ou amostras de swabs orais foram utilizados para amplificar o exon 29 do gene PKD1 pela técnica de PCR-RFLP. De um total de 616 gatos, 27/537 Persas e 1/17 Himalaia mostraram a variante de nucleotídeo único $(\mathrm{C} \rightarrow \mathrm{A})$ na posição 3284 no exon 29 do gene $P K D 1$. Esta variante patogênica foi identificada apenas em heterozigose. A prevalência de DRPAD em gatos Persas e raças relacionadas foram de 5,03\% e 1,6\%, respectivamente. Não houve associações significativas entre raça, gênero ou idade dos felinos e incidência de DRPAD. A prevalência de DRPAD em gatos Persas e raças relacionadas no Brasil foi menor do que em outras partes do mundo, o que pode estar relacionado ao aconselhamento genético e consequente seleção de gatos sem ADPKD para reprodução.
\end{abstract}

Palavras-chave: felino, doença genética, reação em cadeia da polimerase, genotipagem, Felis catus.

\section{Introduction}

Feline autosomal dominant polycystic kidney disease (ADPKD) has been identified in Persian and Persianrelated breeds since late 1960 's, being the most prevalent feline renal inherited disease worldwide. The disease is progressive and characterized by the growth of fluid-filled cysts of different sizes in the renal cortex and medulla and, 
occasionally, in liver and pancreas (Bosje et al., 1998). Similar to the disease presented in humans, ADPKD may result in end-stage kidney disease in affected cats (Biller et al., 1990, 1996; DiBartola, 2000).

Ultrasonographic examination is a useful and reliable method to diagnose ADPKD. Cysts can be identified as hypoechoic to anechoic cavities that are round or oval and well differentiated from the renal parenchyma. Sensitivity and specificity of ultrasonography for cyst detection are $91 \%$ and $100 \%$ at 36 weeks, respectively (Biller et al., 1990). This diagnostic method has been recommended to screen cats older than 10 months (Cannon et al., 2000; Barrs et al., 2001). Recently, our group has established age-based ultrasonographic criteria for the diagnosis of ADPKD in Persian cats (Guerra et al., 2019).

Lyons et al. (2004) identified a single-nucleotide variant (SNV) characterized by a $\mathrm{C}$ to A substitution at position 3284 in exon 29 of feline PKD1, the gene that encodes polycystin-1. This variant results in a premature stop codon in the mRNA, leading to a loss of approximately $25 \%$ of the protein $\mathrm{C}$-terminus. This transversion was found to be heterozygous in Persian and Persian crossbreed cats and was associated with feline ADPKD (Lyons et al., 2004; Young et al., 2005). Importantly, $P K D 1$ genotyping may be helpful to owner's prevention of the disease, because cats do not display significant clinical signs in early stages of the disease and eradication depends on active selection of ADPKD-free cats for reproduction (Helps et al., 2007).

Based on ultrasonographic and molecular methods, the prevalence of ADPKD among Persian, Persian-related breeds and mixed-breed cats has been shown to be approximately $38 \%$ in the United States (Cooper, 2000); $42 \%$ to 50\% in Australia (Barrs et al., 2001; Beck and Lavelle, 2001), 49.2\% in United Kingdom (UK) (Cannon et al., 2001), 40.45\% in France (Barthez et al., 2003), 41\% in Italy (Bonazzi et al., 2009), 36\% in Slovenia (Domanjko-Petrič et al., 2008), $15.7 \%$ in Taiwan (Lee et al., 2010), 33.8\% to $36.8 \%$ in Iran (Tavasolian et al., 2018; Noori et al., 2019), and 46\% in Japan (Sato et al., 2019) with no difference between genders (Barrs et al., 2001; Barthez et al., 2003). In Brazil, however, few studies have determined the prevalence of this disease in specific geographic regions (Ferreira et al., 2010). Based exclusively on ultrasonography analysis, these studies have estimated that ADPKD affects 16\% to $44.6 \%$ of the referred animal population (Alves et al., 2006; Teixeira, 2007; Ondani et al., 2009). More recently, a study revealed a total prevalence of $9 \%$ in 334 tested cats, with positivity of $33 \%$ in Persian cats and $7 \%$ in Brazilian long- and shorthaired cats (Scalon et al., 2014).

Since a relatively accurate prevalence of the disease is essential to assess and justify a screening program and to evaluate its success, the current study was designed to estimate ADPKD prevalence in Persian cats and Persian-related breeds in Brazil employing a genotype determination strategy.

\section{Methods}

\subsection{Study population}

Peripheral blood samples or oral swabs (Endobrush, INLAB $^{\circledR}$, Brazil) from 859 Persian cats and related breeds were submitted to molecular genotyping for the $\mathrm{C}$ to $\mathrm{A}$ transversion in exon 29 of the feline PKD1 gene. Both samples were preserved in RNAlater (Thermo Scientific ${ }^{\circledR}$, USA) and sent by the owners (696 samples) or veterinarians (163 samples) through regular postal mail to the Laboratory of Morphological and Molecular Pathology (LAPMOL) at the Department of Pathology, School of Veterinary Medicine and Animal Sciences, University of São Paulo, São Paulo, Brazil. Samples were stored at $-80^{\circ} \mathrm{C}$ until the DNA extraction. The owners were thoroughly informed about the research protocols and provided their written informed consent. The project was approved by the Ethics Committee on Animal Use of the School of Veterinary Medicine and Animal Science of University of São Paulo (Protocol number: 1812010514).

\subsection{DNA isolation}

DNA was extracted from blood samples $(300 \mu \mathrm{L})$ according to the kit manufacturer's recommendations (Illustra blood genomicPrep Mini Spin Kit, GE Healthcare ${ }^{\circledR}$, USA). Oral swabs were mechanically homogenized (ThermoMixer C, Eppendorf ${ }^{\circledR}$, Germany) in lysis buffer type 1 and then incubated with $20 \mathrm{mg} / \mathrm{ml}$ proteinase $\mathrm{K}$ at $65^{\circ} \mathrm{C}$ for 45 minutes. Subsequently, proteinase $\mathrm{K}$ was inactivated at $95{ }^{\circ} \mathrm{C}$ for 15 minutes and the total product used for DNA extraction following the manufacturer's instructions (Illustra tissue and cells genomic Prep Mini Spin Kit, GE Healthcare ${ }^{\circledR}$, USA). After isolation, DNA concentration was determined using the NanoDrop equipment (NanoDrop Technologies ${ }^{\circledR}$, EUA).

\subsection{Polymerase Chain Reaction (PCR) amplification}

PCR was used to amplify exon 29 of PKD1 gene. A 559 base pair (bp) PCR fragment containing exon 29 was amplified using the primers designed by Domanjko-Petrič et al. (2008): PKD1F1 5'-CAGGTAGACGGGATAGACGA-3' and PKD1R1 5'-TTCTTCCTGGTCAACGACTG-3'. The reaction mixture contained $4 \mu \mathrm{L}$ genomic DNA, $4 \mu \mathrm{L}$ dNTPs $(2.5 \mathrm{mM}$ of each dNTP), $1.5 \mu \mathrm{L}$ magnesium chloride $(25 \mathrm{mM}), 1.25 \mu \mathrm{L}$ PKD1F1 $(10 \mu \mathrm{M}), 1.25 \mu \mathrm{L}$ PKD1R1 $(10 \mu \mathrm{M}), 5 \mu \mathrm{L} 10 \times$ PCR buffer and $0.26 \mu \mathrm{L}$ Taq DNA Polymerase ( $5 \mathrm{U} / \mu \mathrm{L}$; Invitrogen) in a $50 \mu \mathrm{L}$ final volume. The reaction was carried out in a PCR system Mastercycle (Eppendorf ${ }^{\circledR}$, Germany). PCR conditions included initial denaturation for 3 minutes at $94^{\circ} \mathrm{C}, 40$ cycles of amplification with denaturation at $94{ }^{\circ} \mathrm{C}$ for 1 minute, primer annealing at $58{ }^{\circ} \mathrm{C}$ for 1 minute, primer extension at $72{ }^{\circ} \mathrm{C}$ for 1 minute, and a final extension at $72{ }^{\circ} \mathrm{C}$ for 5 minutes. In order to increase sensitivity and specificity for DNA extracted from mucosa oral cells (swabs), nested PCR was also performed with a pair of internal primers: PKD1F2 5'-AACTGTGTCGGCACTCAGC-3' and PKD1R2 5'-GCCTCGTGGAGAAGGAGGT-3' (Lee et al., 2010), a procedure that amplifies a segment of $465 \mathrm{pb}$. The first-round 
PCR product $(2 \mu \mathrm{L})$ was used as a DNA template for the nested PCR, while the concentration of the other reagents and the cycle conditions remained the same.

\subsection{Restriction Fragment Length Polymorphism (RFLP) analysis}

Given that the ADPKD-associated pathogenic variant creates a new MLY1 restriction site, RFLP analysis was applied in the first-round PCR (blood samples) or in nested-PCR (oral samples) products to identify this variant. Approximately $5 \mu \mathrm{L}$ of amplified product was digested at $37^{\circ} \mathrm{C}$ for 3 hours with $10 \mathrm{U}$ of MLY1 (New England Biolabs ${ }^{\circledR}, \mathrm{USA}$ ) in a $10 \mu \mathrm{L}$ reaction containing $1 \times$ NE Buffer 4 , followed by enzyme inactivation at $65{ }^{\circ} \mathrm{C}$ for 10 minutes. The complete digestion reaction was analyzed by electrophoresis on $2 \%$ agarose gels and subsequent documentation using the $\mathrm{ChemiDoc}^{\circledR}$ system (Bio-Rad ${ }^{\circledast}$, USA). Product digestion resulting in two fragments indicated the presence of the $\mathrm{C}$ to $\mathrm{A}$ transversion, whereas observation of only the non-digested $559 \mathrm{bp}$ or $465 \mathrm{pb}$ (in Nested-PCR) fragment revealed absence of this genetic variant (see Figure 1). All reactions included

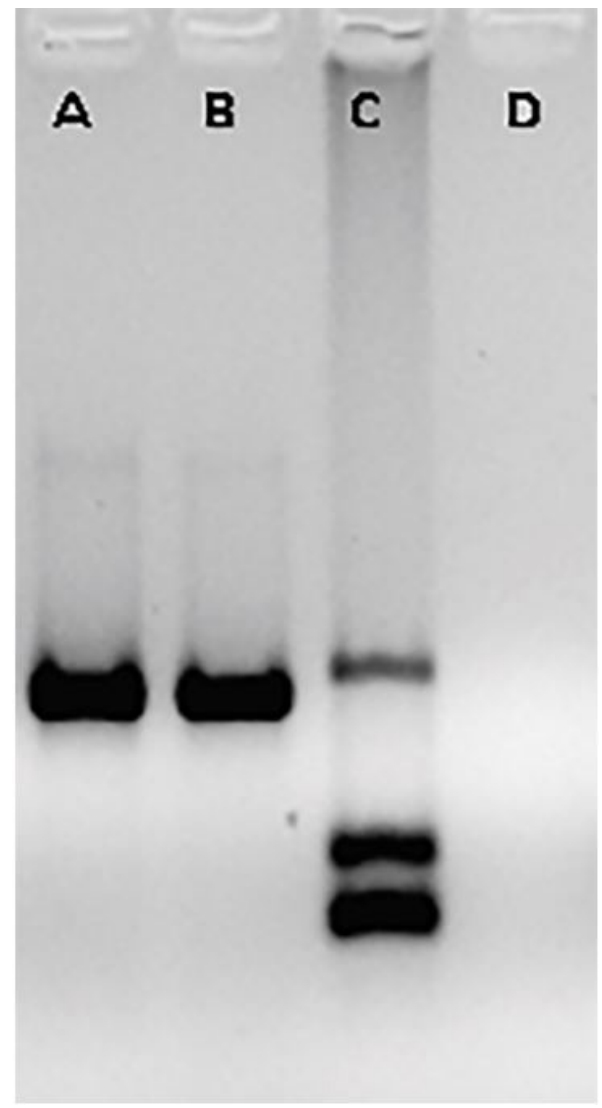

Figure 1. PCR-RFLP for feline ADPKD. Lanes (A) and (B) show unaffected cats with the non-digested PCR product amplified from exon 29 of feline PKD1 gene; Lane (C) shows an ADPKD-affected cat with amplified PCR product digested with the restriction enzyme MLY1 into two fragments; Lane (D) is the negative control (blank). negative controls without DNA template as well as positive controls consisting of a DNA sample from an ADPKD-affected feline diagnosed in a North American reference laboratory. All positive results were confirmed by direct automated Sanger sequencing of the respective amplified PCR products (data not shown).

\subsection{Statistical analysis}

Frequency distributions, variances, Shapiro-Wilk normality test, Student's t-test and Fisher exact test and Pearson chi-squared test were calculated using Minitab 17 (Minitab Inc ${ }^{\circledast}$, USA) and R-project (Stanford University, Stanford, CA, USA). Results were considered statistically significant when $\mathrm{P}<0.05$.

\section{Results}

A total of 859 samples were sent to LAPMOL, of which $675(78.58 \%)$ were obtained by swab from oral mucosa cells and $184(21.42 \%)$ from peripheral whole blood. Despite the use of nested PCR to increase the sensitivity and specificity for DNA obtained from oral swab samples, 243/675 (36\%) cats showed inconclusive results in PCR-RFLP for feline ADPKD diagnostic test. All blood (184) and 64\% (432/675) of oral mucosa samples had conclusive results for molecular testing.

Of the 616 cats with conclusive tests, 537 were Persian, 59 exotic shorthair, 17 Himalayan, 2 Angora and 1 Maine Coon. The age of the cats ranged from 3 to 168 months, with 211 (34.25\%) males and 405 (65.75\%) females. According to Brazilian geopolitical division, the North, Northeast, Center-West, Southeast, and South regions corresponded, respectively, to $0.162 \%$ (1/616), $0.33 \%$ (2/616), $1.62 \%(10 / 616), 79.55 \%(490 / 616)$ and $18.34 \%$ (113/616) of samples.

Regarding the molecular testing, 28 (4.55\%) cats had the $\mathrm{C}$ to $\mathrm{A} \mathrm{SNV}$ in the PKD1 gene, all in heterozygosity (Table 1). Twenty-seven of 537 Persian cats had the pathogenic variant, whereas just one Persian-related breed (Himalayan) presented this variant. All examined exotic shorthair, Angora, and Maine coon cats were negative for the ADPKD-associated variant. Based on this molecular screening, the prevalence of feline ADPKD in Persian cats and related breeds in Brazil was 5.03\% and 1.62\%, respectively. No significant association was found between Persian breed and the presence of the PKD1 gene SNV ( $\mathrm{P}=0.2534)$ by Pearson's chi-squared test.

Eight (28.6\%) of the affected animals were male whereas 20 (71.4\%) of them were female. The ADPKD-related pathogenic variant, however, did not statistically correlate with gender $(\mathrm{P}=0.6566)$ by chi-squared test. ADPKD cats ranged in age from 6 to 162 months (mean age $55.21 \pm 49.22$ months), while non-affected animals aged 3 to 168 months (mean age $43.95 \pm 32.48$ months), these distributions were not statistically different $(\mathrm{P}=0.6523)$. Among the ADPKD cats, 27/28 (96.43\%) of the ADPKD cats lived in the Southeast region while only 1/28 (3.57\%) lived in the South region of Brazil. 
Table 1. Distribution of cats according to the pathogenic variant in exon 29 of the feline $P K D 1$ gene, breed, gender and age.

\begin{tabular}{|c|c|c|c|c|c|}
\hline & & $\begin{array}{c}\text { Positive } \\
\mathrm{N}=28\end{array}$ & $\begin{array}{c}\text { Negative } \\
\mathrm{N}=588\end{array}$ & $\begin{array}{c}\text { Total } \\
\mathrm{N}=616\end{array}$ & P-value \\
\hline \multicolumn{6}{|l|}{ Breed } \\
\hline Persian & N (\%) & $27(96.43)$ & $510(86.74)$ & $537(87.18)$ & $\mathrm{P}=0.2534$ \\
\hline Exotic Shorthair & $\mathrm{N}(\%)$ & $0(0.00)$ & $59(10.04)$ & $59(9.58)$ & \\
\hline Himalayan & $N(\%)$ & $1(3.57)$ & $16(2.72)$ & $17(2.76)$ & \\
\hline Angora & $\mathrm{N}(\%)$ & $0(0.00)$ & $2(0.34)$ & $2(0.32)$ & \\
\hline Maine Coon & $\mathrm{N}(\%)$ & $0(0.00)$ & $1(0.17)$ & $1(0.16)$ & \\
\hline \multicolumn{6}{|l|}{ Gender } \\
\hline Male & $\mathrm{N}(\%)$ & $8(28.57)$ & $203(34.52)$ & $211(34.25)$ & $\mathrm{P}=0.6566$ \\
\hline Female & $\mathrm{N}(\%)$ & $20(71.43)$ & $385(65.48)$ & $405(65.75)$ & \\
\hline \multicolumn{6}{|l|}{ Age (months) } \\
\hline Average & & 55.21 & 43.95 & 41.54 & $\mathrm{P}=0.6523$ \\
\hline Standard deviation & & 49.22 & 32.48 & 32.79 & \\
\hline Median & & 34.00 & 36.00 & 36.00 & \\
\hline Minimum & & 6.00 & 3.00 & 3.00 & \\
\hline Maximum & & 162.00 & 168.00 & 168.00 & \\
\hline
\end{tabular}

\section{Discussion}

Considering the five Brazilian geopolitical regions and applying a molecular-based screening in a population of 616 cats, this study showed that the prevalence of ADPKD in Persian cats and related breeds was $5.03 \%$ and $1.6 \%$, respectively. These results were different from those found in other countries, including the U.S., Australia, UK, France, Italy, Slovenia, Taiwan, Iran and Japan, which showed an estimated $15.7 \%$ to $50 \%$ of Persian cats and related breeds affected by ADPKD diagnosed by ultrasound exam or genetic testing (Cooper, 2000; Barrs et al., 2001; Beck and Lavelle, 2001; Cannon et al., 2001; Barthez et al., 2003; Kappe et al., 2005; Helps et al., 2007; Domanjko-Petrič et al., 2008; Bonazzi et al., 2009; Wills et al., 2009; Lee et al., 2010; Tavasolian et al., 2018; Noori et al., 2019; Sato et al., 2019).

In Brazil, information on prevalence of feline ADPKD is scarce (Ferreira et al., 2010). In a study performed in catteries of Porto Alegre using ultrasound assessment, the authors showed a $44.6 \%$ prevalence of affected cats (Alves et al., 2006). Besides, another study conducted with 116 Persian cats and related breeds in the metropolitan area of Porto Alegre, in the South region of Brazil, revealed a prevalence of $16 \%$ of affected animals by ultrasonography and $26 \%$ through PCR-RFLP-based genetic screening (Teixeira, 2007). Moreover, Ondani et al. (2009) showed a polycystic kidney disease prevalence of only $5.4 \%$ among 130 cats (19 Persian, 18 Siamese and 93 no-defined breed - 74 with short and 19 with long fur) in Jaboticabal region, a municipality of São Paulo State. These animals, however, were exclusively analyzed by ultrasonography, and when only Persian cats were considered, the prevalence reached $31.6 \%$. More recently, Scalon et al. (2014) showed a total ADPKD prevalence of $9 \%$ in 334 cats from the Federal District of Brazil. In addition, this percentage varied greatly according to the origin of the sample. Indeed, while the positivity was $15 \%$ in cats from a veterinary hospital, including animals of all breeds, the overall prevalence was $4 \%$ among samples obtained from animals taken to an anti-rabies vaccination campaign.

Of note, these values were still higher than those found in our study. However, as observed by Scalon et al. (2014), the positivity can be considerably affected by the sample sources. Most studies focus on animals from hospitals and clinics, which display clinical signs that can be first noticed by their owners. This scenario increases the probability of a positive test (Ondani et al., 2009; Scalon et al., 2014). In our study, the largest proportion of analyzed cases included young animals, with no clinical signs of the disease and, therefore, with no selection biases. This fact may have played a role on the lower prevalence observed in our study. Notably, Lyons (2012) reported a significant reduction (about 80\%) in the amount of genetic testing requests for feline ADPKD in the UC Davis Veterinary Genetics Laboratory, showing a drop in the number of animals positive for this disease. This observation reflects successful breeding programs carried out by domestic cat breeders in the U.S. in the last years.

Concerning racial features, all animals with the pathogenic variant in exon 29 of $P K D 1$ gene were Persian or Persian-related breeds, a finding that corroborates the available literature data. These data reveals, indeed, a higher prevalence of ADPKD in Persian cats and related breeds (exotic shorthair, British shorthair, Himalayan, Selkirk Rex, Scottish Fold, Ragdoll, Maine Coon, among others) and crossbreeds, especially those with long fur (Eaton et al., 1997; Ondani et al., 2009). It must be pointed out that no significant age difference was detected between ADPKD and non-ADPKD animals in this study.

Interestingly, data on gender showed a higher proportion of female animals in our studied population. This observation most probably reflects the fact that the analyzed animals belonged only to catteries, where the proportion of females 
is higher than males due to the breeding system. Indeed, some studies have similarly shown a higher number of affected animals among females (Malandain et al., 2009; Ondani et al., 2009; Lee et al., 2010). As expected, however, no gender predisposition for ADPKD was observed within the evaluated cat population, reproducing the findings of other studies (Biller et al., 1996; Barrs et al., 2001; Beck and Lavelle, 2001; Barthez et al., 2003).

In conclusion, we observed a low prevalence of ADPKD in Persian cats and Persian-related breeds in Brazil in comparison to other countries. This finding may be related to empiric genetic counseling and subsequent control of the crossings by breeders. This potential reason should be investigated more profoundly in a future study. It must be noted that our study was completely based on molecular genetic screening while most of the previous studies performed the screening exclusively by ultrasound analysis, a methodology that can potentially generate false-positive cases if the correct criteria are not applied (Guerra et al., 2019). A larger cohort study, however, is still required to determine the prevalence of ADPKD in Persian cats and crossbreds in the Brazilian regions not yet sufficiently represented in the current study.

\section{Acknowledgements}

This work was financially supported by the Fundação de Amparo à Pesquisa do Estado de São Paulo (FAPESP grant numbers 12/19614-6 and 13/06471-5). We are deeply grateful to all owners that agreed to participate in this study.

\section{References}

ALVES, L.C., TEIXEIRA, M.A.C., FISCHER, C. and GRÜN, R., 2006. Prevalência da doença renal policística em gatis de Porto Alegre e grande Porto Alegre. In: Anais do XVII Congresso Estadual de Medicina Veterinária, II Congresso Estadual da Anclivepa, IV Encontro de Especialistas de Pequenos Ruminantes do Conesul, 2006, Gramado, RS. Porto Alegre: SOVERGS.

BARRS, V.R., GUNEW, M., FOSTER, S.F., BEATTY, J.A. and MALIK, R., 2001. Prevalence of autosomal dominant polycystic kidney disease in persan cats and related breeds in Sydney and Brisbane. Australian Veterinary Journal, vol. 79, no. 4, pp. 257-259. http://dx.doi.org/10.1111/j.1751-0813.2001.tb11977.x. PMid:11349412.

BARTHEZ, P.Y., RIVIER, P. and BEGON, D., 2003. Prevalence of polycystic kidney disease in Persian and Persian related in France. Journal of Feline Medicine and Surgery, vol. 5, no. 6, pp. 345-347. http://dx.doi.org/10.1016/S1098-612X(03)00052-4. PMid:14623204.

BECK, C. and LAVELLE, R.B., 2001. Feline polycystic kidney disease in Persian and other cats: a prospective study using ultrasonography. Australian Veterinary Journal, vol. 79, no. 3, pp. 181-184. http://dx.doi.org/10.1111/j.1751-0813.2001.tb14573.x. PMid:11301745.

BILLER, D.S., CHEW, D.J. and DIBARTOLA, S.P., 1990. Polycystic kidney disease in a family of Persian cats. Journal of the American Veterinary Medical Association, vol. 196, no. 8, pp. 1288-1290. PMid:2185204.
BILLER, D.S., DIBARTOLA, S.P., EATON, K.A., PFLUEGER, S., WELLMAN, M.L. and RADIN, M.J., 1996. Inheritance of polycystic kidney disease in Persian cats. The Journal of Heredity, vol. 87, no. 1, pp. 1-5. http://dx.doi.org/10.1093/oxfordjournals. jhered.a022945. PMid:8742815.

BONAZZI, M., VOLTA, A., GNUDI, G., COZZI, M.C., STRILLACCI, M.G., POLLI, M., LONGERI, M., MANFREDI, S. and BERTONI, G., 2009. Comparison between ultrasound and genetic testing for the early diagnosis of polycystic kidney disease in Persian and Exotic Shorthair cats. Journal of Feline Medicine and Surgery, vol. 11, no. 6, pp. 430-434. http://dx.doi. org/10.1016/j.jfms.2008.10.003. PMid:19046910.

BOSJE, J.T., VAN DEN INGH, T.S. and VAN DER LINDESIPMAN, J.S., 1998. Polycystic kidney and liver disease in cats. The Veterinary Quarterly, vol. 20, no. 4, pp. 136-139. http:// dx.doi.org/10.1080/01652176.1998.9694858. PMid:9810628.

CANNON, M.J., BARR, F., GRUFFYDDJONES, T. and GUNNMOORE, D., 2000. Screening for polycystic kidney disease in cats. The Veterinary Record, vol. 147, no. 22, pp. 639-640. PMid:11128083.

CANNON, M.J., BARR, F.J., RUDORF, H., BRADLEY, K.J., GRUFFYDD-JONES, T.J. and MACKAY, A.D., 2001. Prevalence of polycystic kidney disease in Persian cats in the United Kingdom. The Veterinary Record, vol. 149, no. 14, pp. 409-411. http://dx.doi. org/10.1136/vr.149.14.409. PMid:11678212.

COOPER, B., 2000. Autosomal dominant polycystic kidney disease in Persian cats. Feline Practice, vol. 26, pp. 20-21.

DIBARTOLA, S.P., 2000. Autosomal dominant polycystic kidney disease. In: Proceedings of the 18th Annual Veterinary Medical Forum, 2000, Seattle, Washington, USA. Seattle: The American College of Veterinary Internal Medicine, pp. 438-440.

DOMANJKO-PETRIČ, A., CERNEC, D. and COTMAN, M., 2008. Polycystic kidney disease: a review and occurrence in Slovenia with comparison between ultrasound and genetic testing. Journal of Feline Medicine and Surgery, vol. 10, no. 2, pp. 115-119. http://dx.doi.org/10.1016/j.jfms.2007.07.004. PMid:17988914.

EATON, K.A., BILLER, D.S., DIBARTOLA, S.P., RADIN, M.J. and WELLMAN, M.L., 1997. Autosomal dominant polycystic kidney disease in Persian and Persian-cross cats. Veterinary Pathology, vol. 34, no. 2, pp. 117-126. http://dx.doi. org/10.1177/030098589703400204. PMid:9066078.

FERREIRA, G.S., GALVÃO, A.L.B. and SOCHA, J.J.M., 2010. Enfermedad renal poliquística en gatos: Revisión de la literatura/ Polycystic kidney disease in cats: a literature review. Anales de Veterinaria, vol. 26, pp. 23-31.

GUERRA, J.M., FREITAS, M.F., DANIEL, A.G., PELLEGRINO, A., CARDOSO, N.C., DE CASTRO, I., ONUCHIC, L.F. and COGLIATI, B., 2019. Age-based ultrasonographic criteria for diagnosis of autosomal dominant polycystic kidney disease in Persian cats. Journal of Feline Medicine and Surgery, vol. 21, no. 2, pp. 156-164. http://dx.doi.org/10.1177/1098612X18764591. PMid:29652208.

HELPS, C., TASKER, S. and HARLEY, R., 2007. Correlation of the feline PKD1 genetic mutation with cases of PKD diagnosed by pathological examination. Experimental and Molecular Pathology, vol. 83, no. 2, pp. 264-268. http://dx.doi.org/10.1016/j. yexmp.2007.04.002. PMid:17553488.

KAPPE, E.C., HECHT, W., GERWIN, M., MICHELE, U. and REINACHER, M., 2005. Polycystic kidney disease in the German population of Persian cats. A comparative study of ultrasonographical 
examination and genetic testing. Tierärztliche Praxis Kleintiere, vol. 33 , no. 6 , pp. $413-418$.

LEE, Y.J., CHEN, H.Y., HSU, W.L., OU, C.M. and WONG, M.L., 2010. Diagnosis of feline polycystic kidney disease by a combination of ultrasonographic examination and PKD1 gene analysis. The Veterinary Record, vol. 167, no. 16, pp. 614-618. http://dx.doi.org/10.1136/vr.c4605. PMid:21257442.

LYONS, L.A., 2012. Genetic testing in domestic cats. Molecular and Cellular Probes, vol. 26, no. 6, pp. 224-230. http://dx.doi. org/10.1016/j.mcp.2012.04.004. PMid:22546621.

LYONS, L.A., BILLER, S.D., ERDMAN, C.A., LIPINSKI, M.J., YOUNG, A.E., ROE, B., QIN, B. and GRAHN, R.A., 2004. Feline polycystic kidney disease mutation identified in PKD1. Journal of the American Society of Nephrology, vol. 15, no. 10, pp. 25482555. http://dx.doi.org/10.1097/01.ASN.0000141776.38527.BB. PMid:15466259.

MALANDAIN, É., LITTLE, S., CASSELEUX, G., SHELTON, L., PIBOT, P. and PARAGON, B.M., 2009. Concepção e manutenção de um gatil. In: E. MALANDAIN, S. LITTLE, G. CASSELEUX, L. SHELTON, P. PIBOT and B.M. PARAGON, eds. Guia prático de fenicultura. Paris: Royal Canin, cap. 7, pp. 287-313.

NOORI, Z., MOOSAVIAN, H., ESMAEILZADEH, H., VALI, Y. and FAZLI, M., 2019. Prevalence of polycystic kidney disease in Persian and Persian related-cats referred to Small Animal Hospital, University of Tehran, Iran. Iranian Journal of Veterinary Research, vol. 20, no. 2, pp. 151-154. http://dx.doi.org/10.22099/ ijvr.2019.5267. PMid:31531040.

ONDANI, A.C., CARVALHO, M.B., BRUM, A.M. and PEREIRA, M.L., 2009. Prevalência de doença renal policística em gatos domésticos da região de Jaboticabal - São Paulo - Brasil. Veterinária Notícias, vol. 15, no. 2, pp. 89-94.

SATO, R., UCHIDA, N., KAWANA, Y., TOZUKA, M., KOBAYASHI, S., HANYU, N., KONNO, Y., IGUCHI, A.,
YAMASAKI, Y., KURAMOCHI, K. and YAMASAKI, M., 2019. Epidemiological evaluation of cats associated with feline polycystic kidney disease caused by the feline PKD1 genetic mutation in Japan. The Journal of Veterinary Medical Science, vol. 81, no. 7, pp. 1006-1011. http://dx.doi.org/10.1292/jvms.180309. PMid:31155548.

SCALON, M.C., SILVA, T.F., AQUINO, L.C., CARNEIRO, F.T., LIMA, M.G., LEMOS, M.D. and PALUDO, G.R., 2014. Touchdown polymerase chain reaction detection of polycystic kidney disease and laboratory findings in different cat populations. Journal of Veterinary Diagnostic Investigation, vol. 26, no. 4, pp. 542-546. http://dx.doi.org/10.1177/1040638714536561. PMid:24916445.

TAVASOLIAN, P., RAJABIOUN, M., SALARI SEDIGH, H. and AZIZZADEH, M., 2018. Survey of polycystic kidney disease and other urinary tract abnormalities using ultrasonography in Persian and Persian related cats in Iran. Veterinary Research Forum: An International Quarterly Journal, vol. 9, no. 2, pp. 99-103. http:// dx.doi.org/10.30466/VRF.2018.29956. PMid:30065797.

TEIXEIRA, M.A.C., 2007. Análise da prevalência da doença do rim policístico ( $P K D$ ) em felinos da raça persa e assemelhados no Sul do Brasil. Canoas: Universidade Luterana do Brasil, 47 p. Dissertação de Mestrado em Genética e Toxicologia Aplicada.

WILLS, S.J., BARRETT, E.L., BARR, F.J., BRADLEY, K.J., HELPS, C.R., CANNON, M.J. and GRUFFYDD-JONES, T.J., 2009. Evaluation of the repeatability of ultrasound scanning for detection of feline polycystic kidney disease. Journal of Feline Medicine and Surgery, vol. 11, no. 12, pp. 993-996. http://dx.doi. org/10.1016/j.jfms.2009.07.002. PMid:19660972.

YOUNG, A.E., BILLER, D.S., HERRGESELL, E.J., ROBERTS, H.R. and LYONS, L.A., 2005. Feline polycystic kidney disease is linked to the PKD1 region. Mammalian Genome, vol. 16, no. 1, pp. 59-65. http://dx.doi.org/10.1007/s00335-004-2412-2. PMid:15674734. 